\title{
INVENTARISASI SERANGGA PADA POHON TEMBESU (Fragraea fragrans Roxb)
}

\author{
Ria Rosdiana Hutagaol \\ Fakultas Pertanian Universitas Kapuas Sintang \\ Email : riarose.h@gmail.com
}

\begin{abstract}
Abstrak : Penelitian ini bertujuan untuk mengetahui keanekaragaman serangga diurnal (aktif di siang hari) yang terdapat pada Pohon Tembesu (Fagraea fragrans Roxb). Penelitian ini menggunakan metode penelitian deskriptif eksploratif. Lokasi penelitian adalah di Desa Jerora I dan Desa Kapuas Kiri Hulu Kabupaten Sintang, selama 2 minggu efektif di lapangan, yaitu bulan Juli 2016. Pengumpulan data dilakukan dengan teknik inventarisasi dan identifikasi. Identifikasi dilakukan untuk mengetahui taksonomi serangga diurnal pada Pohon Tembesu (Fagraea fragrans Roxb). Analisis data untuk mengetahui keanekaragaman jenis serangga dilakukan dengan menggunakan index Margalef. Hasil analisis data menunjukkan bahwa keanekaragaman jenis serangga tergolong rendah yaitu dengan nilai Indeks Keanekaragaman (D mg) sebesar 2,97 pada Lokasi Jerora I dan 2,39 pada Lokasi Kapuas Kiri Hulu.
\end{abstract}

Kata Kunci : Inventarisasi Serangga, Pohon Tembesu (Fragraea fragrans Roxb)

\section{PENDAHULUAN}

Tembesu (Fragraea fragrans

Roxb) merupakan salah satu jenis kayu yang menjadi unggulan di daerah Kabupaten Sintang. Menurut Junaidah dkk (2014), Tembesu termasuk famili Loganiaceae dan merupakan jenis yang adaptif karena dapat tumbuh pada berbagai jenis tanah dan kondisi lingkungan, seperti pada tanah datar, pasir atau liat berpasir. Selain itu, Tembesu juga dapat tumbuh baik pada tanah dengan drainase yang buruk, termasuk pada daerah rawa.

Kemampuan Tembesu yang dapat tumbuh di berbagai kondisi tempat tumbuh, menyebabkan pohon ini menjadi habitat yang sangat disukai serangga, baik sebagai tempat tinggal maupun sebagai tempat mencari makan. Serangga merupakan salah satu kelompok hewan yang paling beragam dan paling sering dijumpai dalam suatu ekosistem dan memiliki peranan penting dalam ekosistem. Informasi mengenai jenis serangga dan keanekaragaman serangga khususnya pada pohon Tembesu masih sangat terbatas. Oleh karena itu perlu dilakukan penelitian untuk mengetahui jenis serangga dan keanekaragaman jenis serangga pada pohon Tembesu. 


\section{METODE PENELITIAN}

Penelitian ini menggunakan metode Deskriptif Eksploratif. Kawasan yang ditumbuhi pohon Tembesu pada dua lokasi penelitian yaitu Desa Jerora I dan Desa Kapuas Kiri Hulu dijelajah untuk mendapatkan sampel serangga sebanyak-banyaknya. Kegiatan inventarisasi serangga dilakukan pada pagi sampai siang hari yaitu jam $06.00-$

$D m g=\frac{(s-1)}{\log N}$

Keterangan :

$\mathrm{D}_{\mathrm{mg}}=$ Indeks Margalef (Indeks Keanekaragaman Margalef)

$\mathrm{S}=$ Jumlah Spesies

$\mathrm{N}=$ Jumlah Individu

Kriteria Indeks Margalef :

$\mathrm{D}_{\mathrm{mg}}<3,5$ : maka keanekaragaman jenis rendah $3,5<\mathrm{D} \mathrm{mg}<5:$ maka keanekaragaman jenis sedang $\mathrm{D}_{\mathrm{mg}}>5$ : maka keanekaragaman jenis tinggi

\section{HASIL DAN PEMBAHASAN}

\section{A. Jenis Serangga \\ Berdasarkan hasil inventarisasi diperoleh 13 jenis serangga pada pohon Tembesu dimana 8 jenis serangga yang termasuk kedalam 7 ordo yang \\ A. Jenis Serangga I dan 6 jenis serangga yang tergolong ke dalam 4 ordo ditemukan pada Lokasi Desa Kapuas Kiri Hulu. Pada Tabel 1 berikut ini jenis-jenis serangga pada lokasi penelitian Desa Jerora I :}

11.00 WIB. Ukuran tinggi pohon yang diambil sebagai tempat pengambilan sampel serangga adalah pohon dengan tinggi rata-rata 2,5 meter. Analisis data dilakukan dengan identifikasi untuk mengetahui jenis-jenis serangga dan Index Margalef untuk mengetahui keanekaragaman jenis. Rumus Index Margalef adalah sebagai berikut : ditemukan pada Lokasi Penelitian Jerora 
Inventarisasi Serangga Pada Pohon Tembesu (Fragraea fragrans Roxb)

\begin{tabular}{|c|c|c|c|c|}
\hline No. & Jenis & Nama Ilmiah & Ordo & $\begin{array}{c}\text { Jumlah } \\
\text { Individu }\end{array}$ \\
\hline 1. & Lebah tanah & Anoplius atrox & Hymenoptera & 1 \\
\hline 2. & Belalang Kayu & $\begin{array}{l}\text { Valanga } \\
\text { nigricornis }\end{array}$ & Orthoptera & 2 \\
\hline 3. & $\begin{array}{ll}\begin{array}{l}\text { Semut } \\
(\text { Kerangga })\end{array} & \text { Rangrang } \\
\end{array}$ & $\begin{array}{l}\text { Oecophylla } \\
\text { smaragdina }\end{array}$ & Hymenoptera & 203 \\
\hline 4. & Kepik Daun & Nezara viridula & Hemiptera & 11 \\
\hline 5. & Kumbang Tanah & Carbidae & Coleoptera & 2 \\
\hline 6. & Capung & Neurothemis & Odonata & 4 \\
\hline 7. & Serangga Ranting & $\begin{array}{l}\text { Diapheromera } \\
\text { femorata }\end{array}$ & Phasmida & 1 \\
\hline 8. & Kupu-Kupu & $\begin{array}{l}\text { Lampides } \\
\text { monarch }\end{array}$ & Lepidoptera & 2 \\
\hline \multicolumn{4}{|c|}{ Jumlah } & 226 \\
\hline
\end{tabular}

Sumber : Data Hasil Penelitian, 2016

Pada lokasi penelitian di Desa Kapuas 6 jenis serangga yang tergolong ke dalam

Kiri Hulu, hasil inventarisasi ditemukan

4 ordo, sebagai berikut :

Tabel 2. Jenis-jenis Serangga yang Ditemukan Pada Lokasi Penelitian Desa Kapuas Kiri Hulu

\begin{tabular}{|c|c|c|c|c|}
\hline No. & Jenis & Nama Ilmiah & Ordo & $\begin{array}{c}\text { Jumlah } \\
\text { Individu }\end{array}$ \\
\hline 1. & $\begin{array}{ll}\text { Semut } & \text { Rangrang } \\
\text { (Kerangga) } & \\
\end{array}$ & $\begin{array}{l}\text { Oecophylla } \\
\text { smaragdina }\end{array}$ & Hymenoptera & 116 \\
\hline 2. & Semut Hitam & $\begin{array}{l}\text { Dolichoderus } \\
\text { thoracicus Smith }\end{array}$ & Hymenoptera & 4 \\
\hline 3. & Belalang Sembah & Mantis religiosa & Orthoptera & 1 \\
\hline 4. & Kumbang Daun & Chrysomelidae & Coleoptera & 2 \\
\hline 5. & Kutu Daun & Helopeltis antonii & Hemiptera & 1 \\
\hline 6. & Wereng & Nilaparvata & Hemiptera & 1 \\
\hline \multicolumn{4}{|c|}{ Jumlah } & 125 \\
\hline
\end{tabular}

Sumber : Data Hasil Penelitian, 2016

B. Indeks Keanekaragaman

Indeks keanekaragaman dapat diukur dengan menggunakan Index 
Margalef, dimana keanekaragaman suatu jenis dipengaruhi oleh jumlah spesies (s) dan jumlah individu pada suatu spesies $(\mathrm{N})$. Hasil analisis data dengan menggunakan Index Margalef diketahui bahwa nilai kanekaragaman serangga di lokasi penelitian Desa Jerora I adalah 2,97 dan pada lokasi penelitian di Desa Kapuas Kiri Hulu adalah 2,39. Berdasarkan kriteria index Margalef keanekaragaman jenis serangga pada kedua lokasi penelitian termasuk ke dalam kriteria keanekaragaman jenis yang rendah.

Rendahnya keanekaragaman jenis suatu jenis serangga dapat dipengaruhi oleh berbagai faktor. Menurut Untung (1993), populasi serangga berkembang tergantung pada dua faktor yaitu Potensi Biotik (Biotic Potential) dan Lingkungan (Environment Resistance).

Berdasarkan pengamatan, diketahui bahwa faktor lingkungan yang terdiri dari faktor fisik, faktor biotis (predator dan patogen) serta faktor makanan lebih menjadi penyebab rendahnya keanekaragaman jenis serangga pada lokasi penelitian. Faktor fisik berupa cuaca yang seringkali berubah-ubah dalam waktu singkat serta angin disertai hujan pada saat pengamatan, menjadi faktor penyebab rendahnya keanekaragaman jenis. Pada saat hujan, serangga mencari tempat berlindung dan air hujan yang jatuh. Hal ini ditegaskan oleh Adler (Pradana, dkk, 2011), bahwa cuaca sangat berpengaruh terhadap diversitas serangga seperti halnya suhu. Dalam cuaca hujan, serangga akan bersembunyi dari air hujan, apabila sayap serangga basah oleh air hujan maka serangga tidak dapat terbang dengan mudah sehingga dapat dengan mudah dimangsa oleh predator.

\section{KESIMPULAN}

Hasil penelitian menunjukkan bahwa terdapat 13 jenis serangga pada Pohon Tembesu (Fragraea fragrans Roxb). Nilai kanekaragaman jenis serangga di lokasi penelitian Desa Jerora I adalah 2,97 dan pada lokasi penelitian di Desa Kapuas Kiri Hulu adalah 2,39. Berdasarkan kriteria index Margalef keanekaragaman jenis serangga pada kedua lokasi penelitian termasuk ke dalam kriteria keanekaragaman jenis yang rendah. 


\section{DAFTAR PUSTAKA}

Akbar, KM., Mutiara. 2015. Jenis-jenis Serangga Nocturnal pada Tanaman Duku (Lansium domesticum Corr) di Desa Sari Geni Lama OKI Sumatera Selatan. Jurnal Biologi Fakultas MIPA. Vol.12 No.1 Juni 2015.

Junaidah, Sofyan.A., Nasrun. 2014. Tembesu Kayu Raja Andalan Sumatera. Bandung : Forda Press

Pracaya. 2005. Hama dan Penyakit Tanaman. Jakarta : Penebar Swadaya

Pradana, P., Ni Luh W, Ni Made S. 2011. Inventarisasi Serangga Pada Perkebunan Kakao Laboratorium Unit Perlindungan Tanah Desa

Bedulu Kecamatan Belah Batu Kabupaten Gianyar Bali. Jurnal Biologi XIV (1): 19-24

Untung, K. 1993. Pengantar Pengelolaan Hama Terpadu. Yogyakarta : Gadjah Mada niversity Press. 